\title{
Establishment of Tissue Culture Regeneration System for Medicago ruthenica L. cv. 'Zhilixing'
}

Bo $\mathrm{Xu}^{\#}$, Rina $\mathrm{Wu}^{\#}$, Cuiping Gao, Fengling Shi

10.18805/LRF-659

\begin{abstract}
Background: Medicago ruthenica L. Zhilixing' is a new variety with superior forage and seed yield compared to the wild type. The cold, drought and salt tolerance of Zhlixing are better than those of alfalfa, suggesting that this variety can serve as a high-quality genetic resource for improving the stress resistance of alfalfa. However, because of the lack of tissue culture regeneration system, it is difficult to perform genetic transformation studies on stress resistance genes. This study aimed to establish an efficient tissue culture regeneration system for Zhilixing variety.

Methods: Three types of explants were selected and tested on four types of basal media supplemented with different combinations of auxin and cytokinin for callus induction and differentiation, based on orthogonal tests to select the combinations of auxin and cytokinin suitable for callus induction and differentiation. Two-factor combination method was used to formulate a suitable rooting medium.

Result: The hypocotyledonary axis was found to be an excellent explant for callus induction on MS medium. The optimum callus induction medium contained thidiazuron (TDZ, $0.5 \mathrm{mg} / \mathrm{L}$ ), 2,4-dichlorophenoxyacetic acid (2,4-D, $1.0 \mathrm{mg} / \mathrm{L}$ ) and naphthaleneacetic acid (NAA, $0.5 \mathrm{mg} / \mathrm{L}$ ) where the callus induction rate was $93.33 \%$. The differentiation medium was supplemented with TDZ $(0.75 \mathrm{mg} / \mathrm{L})$, 2,4-D $(0.25 \mathrm{mg} / \mathrm{L})$ and 6-benzyladenine $(6-\mathrm{BA}, 1.5 \mathrm{mg} / \mathrm{L})$ where the differentiation rate was $63.33 \%$. Thidiazuron played the key role in both processes of callus induction and differentiation. Half-strength MS containing $0.1 \mathrm{mg} / \mathrm{L}$ of NAA was the most efficient rooting medium.
\end{abstract}

Key words: Callus, Differentiation, Medicago ruthenica, TDZ, Tissue culture.

\section{INTRODUCTION}

Medicago ruthenica is a perennial forage plant of the Leguminosae that is widely distributed in high mountains (Balabaev, 1934) and typical and desertified grasslands in northern China (Shu et al., 2018). It has a great potential for use in many fields such as grassland improvement, ecological management and grass industry development. The nutrient value utilization efficiency for Medicago ruthenica has been reported to be higher compared with alfalfa (Wu et al., 2020). The cold and drought resistance as well as salt and alkali tolerance were reported to be better than those of alfalfa, but the yield was lower (Yang et al., 2011). Because of its high tolerance to various extreme environmental conditions (Campbell et al., 1999; Guan et al., 2009), Medicago ruthenica can be used as a high-quality genetic resource for improving the stress resistance of alfalfa and other pastures.

In recent years, research on Medicago ruthenica mainly focused on the responses to abiotic stress (Shu et al., 2018), evaluation and analysis of germplasm genetic diversity (Wang et al., 2020) and screening, cloning and functional verification of resistance genes (Yin et al., 2021; Liu, 2020). The functional verification of Medicago ruthenica resistance genes was mainly carried out on model plants. Reports on gene over-expression or knockout in Medicago ruthenica are scarce if at all, mainly because a genetic transformation and regeneration system for Medicago ruthenica is yet to be established.
College of Grassland, Resources and Environment, Inner Mongolia Agricultural University, Hohhot, China.

\#These authors contributed equally to this work.

Corresponding Author: Fengling Shi, College of Grassland, Resources and Environment, Inner Mongolia Agricultural University, Hohhot, China. Email: nmczysfl@126.com

How to cite this article: Xu, B., Wu, R., Gao, C. and Shi, F. (2021). Establishment of Tissue Culture Regeneration System for Medicago ruthenica L. cv. 'Zhilixing'. Legume Research. DOI: $10.18805 /$ LRF-659.

Submitted: 30-09-2021 Accepted: 23-11-2021 Online: 25-12-2021

Successful genetic transformation requires an efficient tissue culture protocol (Mehmet et al., 2021). The regeneration process from tissue culture is very complex and is affected by many factors, such as basal media, types and genotypes of explants, growth conditions and types and combinations of phytohormones (Xu et al., 2021). Currently, the tissue culture of Medicago ruthenica traditionally utilizes mature embryos, stems, leaves and hypocotyledonary axis as explants to produce calli capable of regenerating plantlets (Bian et al., 2009; Zhang et al., 2009; Jin et al., 1997; Liu et al., 1990). However, it is costly and time consuming to cultivate donor plants to obtain mature embryos, stem and leaf explants (Mehmet et al., 2021) and the results of the reported studies have shown that callus induction rates were less than $50 \%$ (Tao et al., 2011). In a previous experiment, we 
used hypocotyledonary axis as an explant to produce callus and the callus induction rate was $91 \%$, but most of the calli were non-embryogenic. The differentiation rate was only $15 \%$ and few shoots generated roots (Bian et al., 2009). In view of the above information, it is necessary to establish an efficient tissue culture regeneration system for Medicago ruthenica.

In China, multiple mixed selection methods were used to breed the new variety hereafter named as Medicago ruthenica L. cv. 'Zhilixing'. Compared with the wild type, the new variety has an upright plant type, which is easier to harvest and has higher forage and seed yield. We plan for future in-depth research on the screening of resistance genes and genetic transformation of this variety. The whole genome of Medicago ruthenica has been published and this information together with the availability of a regeneration system could be of great significance for research on genetic transformation (Yin et al., 2021). Therefore, in this study, three types of explants were selected and tested on four types of basal media for callus induction and plantlet regeneration. We adopted orthogonal experiments to select different combinations of auxins and cytokininsmitogens, aiming to establish a complete and efficient tissue culture regeneration system of Medicago ruthenica L. Cv. Zhilixing' and lay basis for research on its genetic transformation.

\section{MATERIALS AND METHODS}

The experiment was conducted rabi session of 2019-11 and 2020-7 at the research farm of Inner Mongolia Agricultural University, Hohhot in Inner Mongolia, China. The tissue culture and regeneration system was established using Medicago ruthenica L. cv. Zhilixing. The plants were grown to maturity and seeds were collected.

\section{Preparation and culturing of explants}

The seeds were soaked in $\mathrm{H}_{2} \mathrm{SO}_{4}$ for 7 min to break the hard coats, rinsed with running water for $30 \mathrm{~min}$. The seeds were then sterilized with $75 \%$ ethanol for $1 \mathrm{~min}$ and rinsed with sterile water three times and cultured into bottles (ten seeds per bottle) containing MS, B5, N6, or Nitsch basal media. After 5-7 days, the cotyledons, hypocotyledonary axes and roots were separated where the length of each explant was 3-5 $\mathrm{mm}$. The explants were inoculated onto the same basal media used for germination.

\section{Callus induction}

Based on 3-factor and 4-level orthogonal design, different concentrations ( $0 \mathrm{mg} / \mathrm{L}, 0.25 \mathrm{mg} / \mathrm{L}, 0.5 \mathrm{mg} / \mathrm{L}, 0.75 \mathrm{mg} / \mathrm{L})$ of TDZ, 2,4-D and NAA as well as sucrose $(20.0 \mathrm{~g} / \mathrm{L})$ and agar $(6.0 \mathrm{~g} / \mathrm{L})$ were used to formulate the callus induction media. The $\mathrm{pH}$ of all media was set at 5.8. The gradient was set according to $\mathrm{L}_{16}\left(4^{3}\right)$. Each culture bottle was inoculated with five explants and each treatment was repeated six times. The callus induction rate was determined after 20 days.

\section{Callus differentiation}

The callus were transferred to differentiation media after a sub-generation culture (25 days). According to 3-factor and 4-level orthogonal design, the regeneration media contained different concentrations of TDZ $(0 \mathrm{mg} / \mathrm{L}, 0.25 \mathrm{mg} / \mathrm{L}, 0.5 \mathrm{mg} / \mathrm{L}$, $0.75 \mathrm{mg} / \mathrm{L}), 2,4-\mathrm{D}(0 \mathrm{mg} / \mathrm{L}, 0.25 \mathrm{mg} / \mathrm{L}, 0.5 \mathrm{mg} / \mathrm{L}, 0.75 \mathrm{mg} / \mathrm{L})$ and $6-B A(0.5 \mathrm{mg} / \mathrm{L}, 1 \mathrm{mg} / \mathrm{L}, 1.5 \mathrm{mg} / \mathrm{L}, 2 \mathrm{mg} / \mathrm{L})$, hydrolyzed casein $(0.5 \mathrm{~g} / \mathrm{L})$, sucrose $(20.0 \mathrm{~g} / \mathrm{L})$ and agar $(7.0 \mathrm{~g} / \mathrm{L})$. The $\mathrm{pH}$ of all media was set to 5.8. Each culture bottle was inoculated with five calli. Each treatment included five replicates and the differentiation rates were analyzed after 15-20 days.

\section{Rooting of shoots}

The generated shoots were cultured onto the rooting media. The basic medium was either MS or half-strength MS supplemented with NAA $(0 \mathrm{mg} / \mathrm{L}, 0.1 \mathrm{mg} / \mathrm{L}$ or $0.2 \mathrm{mg} / \mathrm{L})$, sucrose $(20.0 \mathrm{~g} / \mathrm{L})$ and agar $(7.0 \mathrm{~g} / \mathrm{L})$. The $\mathrm{pH}$ of all media was adjusted to 5.8. Each culture bottle was inoculated with three differentiated shoots. Each treatment included five replicates and the rooting rate was determined after 15 days. The regenerated complete plantlets were transferred to the field.

\section{Statistical analyses}

The callus induction and differentiation rates as well as shoot rooting rates were analyzed via analysis of variance (ANOVA, $p<0.05$ ).

Callus induction rate $(\%)=$

$$
\frac{\text { Number of calli induced }}{\text { Number of explants inoculated }} \times 100 \%
$$

Differentiation rate $(\%)=$

$$
\frac{\text { Number of differentiated calli }}{\text { Number of inoculated calli }} \times 100 \%
$$

Rooting rate $(\%)=$

$$
\frac{\text { Number of rooted shoots }}{\text { Number of inoculated shoots }} \times 100 \%
$$

\section{RESULTS AND DISCUSSION}

\section{Selection of suitable basal medium and explant}

The growth and differentiation of calli were significantly affected by genotypes and explants (Alatar et al., 2017). In four kinds of basal media without hormones, the three kinds of explants induced calli. Among them, the hypocotyledonary axes showed the highest callus induction rate, followed by the cotyledons and roots (Fig 1). When the root was used as an explant, it was almost difficult to produce calli on the four basal media, in agreement with the previously reported results in wheat (Mehmet et al., 2021; Sarker and Biswas, 2002). The hypocotyledonary axis had the highest callus induction rate on MS medium (over $30 \%$ ), followed by B5 (20\%), N6 (16.7\%) and then Nitsch (10\%). Thus, MS basal medium was recommended for follow-up research (Alatar et al., 2017; Bian et al., 2009). 


\section{The effect of different hormone concentrations on callus induction rate}

Cytokinin and auxin play vital roles in the induction and differentiation of calli (Verma et al., 2016). However, attention should be paid to calli induction rate and also to the state of calli, so as to increase the probability of formation of embryogenic calli (Liu et al., 2016). As shown in Table 1, A10, A11 and A12 culture media induced compact embryogenic calli with light yellow or green color (Fig 2-A) where the callus induction rate was higher than on other media. Although A7 showed a high callus induction rate, the calli were almost non-embryogenic. In general, the optimum medium for callus induction contained TDZ (0.5 $\mathrm{mg} / \mathrm{L}), 2,4-\mathrm{D}(1.0 \mathrm{mg} / \mathrm{L})$ and NAA $(0.5 \mathrm{mg} / \mathrm{L})(\mathrm{A} 7)$, where the rate of callus induction was $93.33 \%$.

\section{TDZ plays the key role in callus induction}

When TDZ was omitted from the media (A1through A4), the callus induction rates were relatively low (33.33\%-40\%) and most of the calli were non-embryogenic. In our previous research, TDZ was not used for inducing calli, which may have been one of the reasons for the low differentiation rates reported (Bian et al., 2009). The present study shows that calli derived from hypocotyledonary axes were stimulated by TDZ to regenerate shoots (Miroshnichenko et al., 2017). Compared with the previous study, TDZ obviously improved the development of embryogenic calli (Bian et al., 2009; Ruduś et al., 2001). The results of the range analysis (Table 3) also proved that TDZ played the most crucial role in callus induction from the hypocotyledonary axes (Aslam et al., 2020).

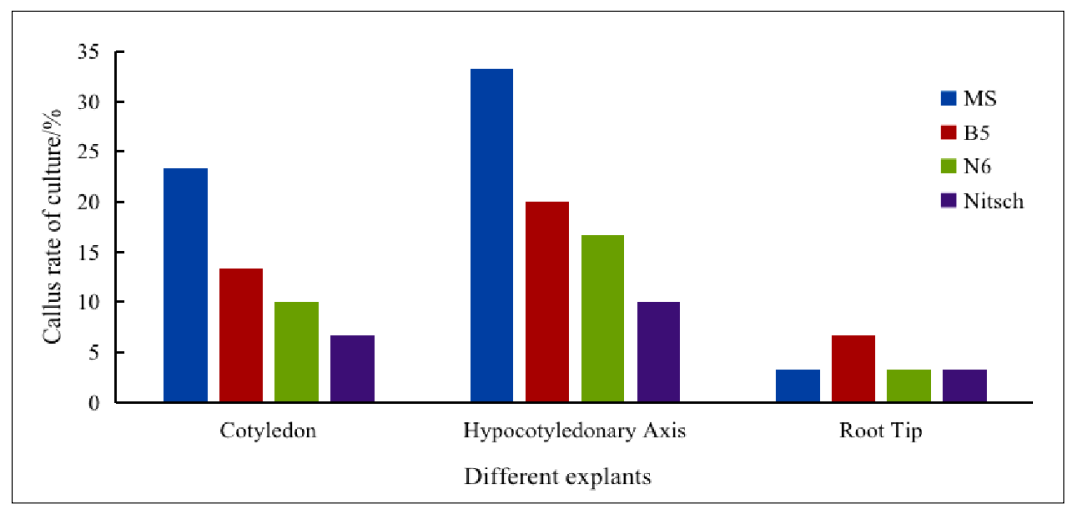

Fig 1: The callus rate of different explants in 4 kinds of basic medium.

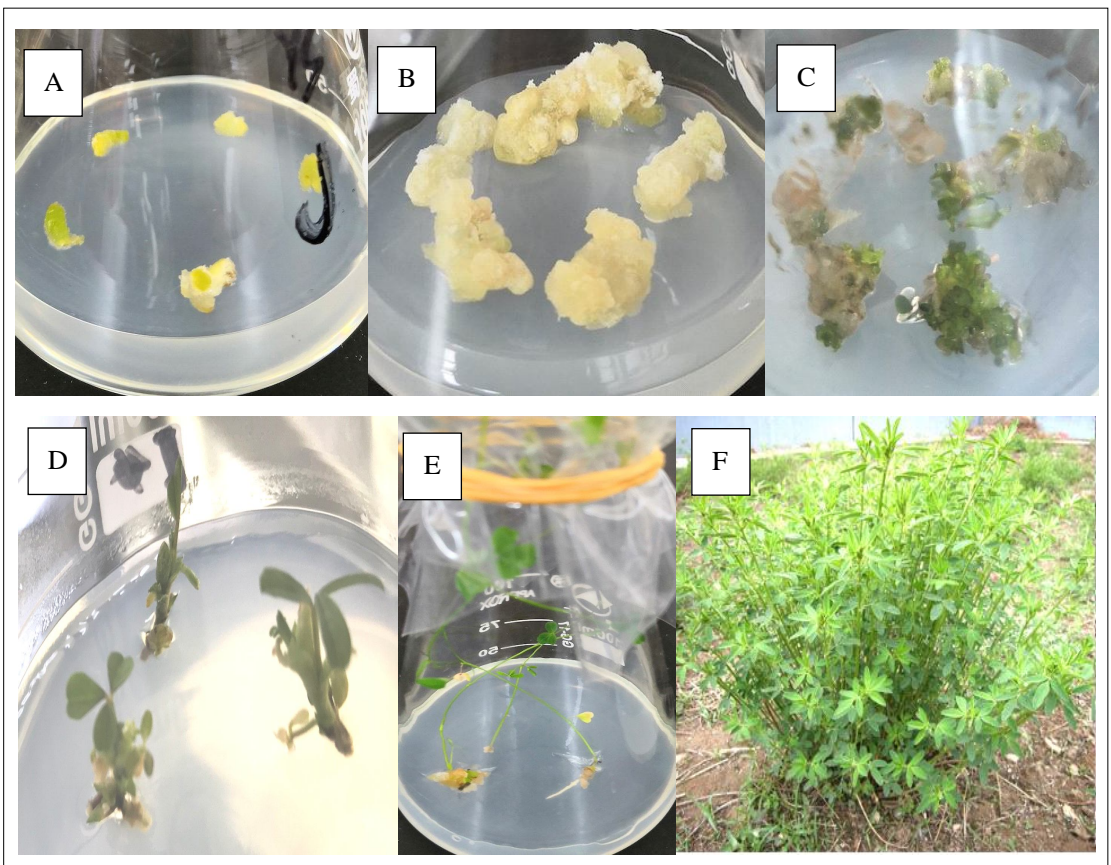

Fig 2: Anther tissue culture regeneration process of Medicago ruthenica L. 'Zhilixing' .

A- Callus induced by hypocotyledonary axis; B- Callus after subculture; C- Callus differentiation; D- Differentiated seedlings; E- Regenerated plants; F- Live plants after transplanted. 
Establishment of Tissue Culture Regeneration System for Medicago ruthenica L. cv. 'Zhilixing'

Table 1: Callus induction rate of the hypocotyledonary axes cultured on different hormone concentrations.

\begin{tabular}{lcccll}
\hline Number & TDZ $\left(\mathrm{mg} \cdot \mathrm{L}^{-1}\right)$ & $2,4-\mathrm{D}\left(\mathrm{mg} \cdot \mathrm{L}^{-1}\right)$ & $\mathrm{NAA}\left(\mathrm{mg} \cdot \mathrm{L}^{-1}\right)$ & Callus induction rate $(\%)$ & Callus appearance \\
\hline A1 & 0 & 0 & 0 & $36.67 \mathrm{ef}$ & Loose, brownness \\
A2 & 0 & 0.25 & 0.25 & $33.33 \mathrm{f}$ & Loose, slight green \\
A3 & 0 & 0.5 & 0.5 & $36.67 \mathrm{ef}$ & Loose, light yellow \\
A4 & 0 & 0.75 & 0.75 & $40.00 \mathrm{def}$ & Loose, green with slight brownness \\
A5 & 0.25 & 0 & 0.25 & $46.67 \mathrm{cdef}$ & Compact, light brownness \\
A6 & 0.25 & 0.25 & 0.5 & $50.00 \mathrm{cde}$ & Compact, slight green \\
A7 & 0.25 & 0.5 & 0.75 & $60.00 \mathrm{c}$ & Loose, light brownness \\
A8 & 0.25 & 0.75 & 0 & $50.00 \mathrm{cde}$ & Loose, light yellow \\
A9 & 0.5 & 0 & 0.5 & $53.33 \mathrm{~cd}$ & Loose, light brownness \\
A10 & 0.5 & 0.25 & 0.75 & $76.67 \mathrm{~b}$ & Compact, light yellow \\
A11 & 0.5 & 0.5 & 0 & $60.00 \mathrm{c}$ & Compact, light green \\
A12 & 0.5 & 0.75 & 0.25 & $93.33 \mathrm{a}$ & Compact, light yellow \\
A13 & 0.75 & 0 & 0.75 & $36.67 \mathrm{ef}$ & Loose, light yellow \\
A14 & 0.75 & 0.25 & 0 & $50.00 \mathrm{cde}$ & Loose, green \\
A15 & 0.75 & 0.5 & 0.25 & $50.00 \mathrm{cde}$ & Loose, green \\
A16 & 0.75 & 0.75 & 0.5 & $50.00 \mathrm{cde}$ & Loose, light yellow \\
\hline
\end{tabular}

TDZ-Thidiazuron; 2.4-D - 2,4-Dichlorophenoxyacetic acid; NAA- Naphthylacetic acid.

Table 2: Callus differentiation rate of Medicago ruthenica L. Cv. Zhilixing under different hormone ratio.

\begin{tabular}{lcccc}
\hline Number & $\begin{array}{c}\text { TDZ } \\
\left(\mathrm{mg} . \mathrm{L}^{-1}\right)\end{array}$ & $\begin{array}{c}2,4-\mathrm{D} \\
\left(\mathrm{mg} \cdot \mathrm{L}^{-1}\right)\end{array}$ & $\begin{array}{c}6-\mathrm{BA}) \\
\left(\mathrm{mg} . \mathrm{L}^{-1}\right.\end{array}$ & $\begin{array}{c}\text { Differentiation } \\
\text { rate }(\%)\end{array}$ \\
\hline B1 & 0.25 & 0.25 & 0.5 & $43.33 \mathrm{~b}$ \\
B2 & 0.25 & 0.5 & 1 & $13.33 \mathrm{def}$ \\
B3 & 0.25 & 0.75 & 1.5 & $10.00 \mathrm{def}$ \\
B4 & 0.25 & 1 & 2 & $16.67 \mathrm{cde}$ \\
B5 & 0.5 & 0.25 & 0.5 & $20.00 \mathrm{~cd}$ \\
B6 & 0.5 & 0.5 & 1 & $26.67 \mathrm{c}$ \\
B7 & 0.5 & 0.75 & 1.1 & $50.00 \mathrm{~b}$ \\
B8 & 0.5 & 1 & 0.5 & $43.33 \mathrm{~b}$ \\
B9 & 0.75 & 0.25 & 1.5 & $63.33 \mathrm{a}$ \\
B10 & 0.75 & 0.5 & 2 & $20.00 \mathrm{~cd}$ \\
B11 & 0.75 & 0.75 & 0.5 & $46.67 \mathrm{~b}$ \\
B12 & 0.75 & 1 & 1 & $40.00 \mathrm{~b}$ \\
B13 & 1 & 0.25 & 2 & $3.33 \mathrm{f}$ \\
B14 & 1 & 0.5 & 0.5 & $6.67 \mathrm{ef}$ \\
B15 & 1 & 0.75 & 1 & $10.00 \mathrm{def}$ \\
B16 & 1 & 1 & 1.5 & $10.00 \mathrm{def}$ \\
\hline
\end{tabular}

TDZ-Thidiazuron; 2.4-D - 2,4-Dichlorophenoxyacetic acid; 6-BA 6-Benzylaminopurine.

\section{The effect of different hormone concentrations on callus differentiation}

Plant growth regulators play the key role in callus differentiation (Takatsuka and Umeda, 2014). Depending on the genotype, a regeneration system for a given species requires a specific combination of auxin and cytokinin (Mehtab et al., 2020). In this study, the optimum concentration of hormones was TDZ (0.75 mg/L), 2,4-D (0.25 mg/L) and 6-BA $(1.5 \mathrm{mg} / \mathrm{L})(\mathrm{B} 9)$ where the differentiation rate was $63.33 \%$ (Table 2). Indeed, TDZ again determined the callus differentiation rate (Table 3 ). When the concentration of TDZ was $0.75 \mathrm{mg} / \mathrm{L}$, a large number of differentiated shoots was obtained, but higher concentration $(1 \mathrm{mg} / \mathrm{L})$ caused the calli to lose viability, lose the ability to differentiate or even die. This suggests that TDZ was an effective plant growth regulator for Medicago ruthenica regeneration (Mehmet et al., 2021). Furthermore, range analysis showed that 2,4-D and 6-BA also played roles in the differentiation process (Table 3). Addition of 2,4-D has been reported to promote the differentiation of calli and indirectly increase the differentiation rate (Mahmood and Razzaq, 2017). Appropriate levels of 6-BA have also been reported to reduce the browning rate and effectively improve the quality of calli (Xu et al., 2021).

Table 3: Range analysis of callus induction and differentiation rates.

\begin{tabular}{lccccccc}
\hline Induction rate of callus & TDZ & 2,4-D & NAA & Differentiation rate & TDZ & $2,4-D$ & 6 -BA \\
\hline K1 mean value & 0.37 & 0.43 & 0.48 & K1 mean value & 0.21 & 0.33 & 0.35 \\
K2 mean value & 0.51 & 0.53 & 0.55 & K2 mean value & 0.35 & 0.17 & 0.21 \\
K3 mean value & 0.71 & 0.51 & 0.48 & K3 mean value & 0.43 & 0.29 & 0.28 \\
K4 mean value & 0.46 & 0.58 & 0.53 & K4 mean value & 0.08 & 0.28 & 0.23 \\
R & 0.34 & 0.14 & 0.08 & R & 0.35 & 0.16 & 0.14 \\
\hline
\end{tabular}

TDZ-Thidiazuron; 2.4-D - 2,4-Dichlorophenoxyacetic acid; NAA- Naphthylacetic acid; 6-BA - 6-Benzylaminopurine. K1, K2, K3 and K4 mean values were induction rate of callus and differentiation rate of three factors in every level. $R$ was the range of the same factor in every level $\left(R=K_{\text {max }}-K_{\text {min }}\right)$. 
Table 4: Comparison of callus rooting rate of Medicago ruthenica L. cv. Zhilixing.

\begin{tabular}{lccc}
\hline Number & Basal medium & $\mathrm{NAA}\left(\mathrm{mg} \cdot \mathrm{L}^{-1}\right)$ & Rooting rate $(\%)$ \\
\hline C1 & $\mathrm{MS}$ & 0 & $46.6 \mathrm{~cd}$ \\
$\mathrm{C} 2$ & $\mathrm{MS}$ & 0.1 & $53.4 \mathrm{bcd}$ \\
C3 & $\mathrm{MS}$ & 0.2 & $33.0 \mathrm{~d}$ \\
C4 & $1 / 2 \mathrm{MS}$ & 0 & $73.6 \mathrm{~b}$ \\
C5 & $1 / 2 \mathrm{MS}$ & 0.1 & $93.4 \mathrm{a}$ \\
C6 & $1 / 2 \mathrm{MS}$ & 0.2 & $60.2 \mathrm{bc}$ \\
\hline
\end{tabular}

NAA- Naphthylacetic acid.

\section{Effect of different types of media and hormone concentrations on the rooting of shoots}

The rooting rate of differentiated shoots on half-strength MS basal medium supplemented with $0.1 \mathrm{mg} / \mathrm{L}$ NAA was significantly higher than these on C4 and C5 ( $p<0.05$, Table 4). Similar results have been obtained for alfalfa ( $\mathrm{Xu}$ et al., 2021). Adding a low concentration of NAA to the rooting medium was supportive to the rooting of differentiated shoots, but excessive NAA inhibited the rooting process (Liu et al., 2016). After the rooted seedlings were cultured for 20 days, they were transplanted into soil where the survival rate was more than $90 \%$.

\section{ACKNOWLEDGEMENT}

Fengling Shi designed the experiment, Bo Xu and Rina Wu performed the experiments and wrote the manuscript, Cuiping Gao revised the article. Bo Xu and Rina Wu contribute equally in this manuscript. Thanks to Key Laboratory of Grassland Resources, Ministry of Education P.R. of China. This study was supported by the financial project of the Inner Mongolia Autonomous Region (RZ1900008322) and the Science and technology project of the Inner Mongolia Autonomous Region (2019GG244). The authors would like to express their gratitude to EditSprings for the expert linguistic services provided.

\section{REFERENCES}

Alatar, A.A., Mohammad, F., Eslam, M.A., Tomas, C., Quaiser, S., Saad, B.J., Mohamed, A.E., Abdulaziz, A.A. (2017). Efficient and reproducible in vitro regeneration of Solanum lycopersicum and assessment genetic uniformity using flow cytometry and SPAR methods. Saudi Journal of Biological Sciences. 4(6): 1430-1436.

Aslam, M.M., Karanja, J.K., Zhang, Q., Lin, H.F., Xia, T.Y., Akhtar, K., Liu, J.P., Miao, R., Xu, F.Y., Xu, W.F. (2020). In vitro regeneration potential of white lupin (Lupinus albus) from cotyledonary nodes. Plants. 9(3): 318.

Balabaev, G.A. (1934). Yellow lucernes of Siberia, Medicago ruthenica (L.) Lebd. and M. platycarpos (L.) Lebd. Bulletin of Applied Botany of Genetic and Plant Breeding Service. 7: 13-123.

Bian, X.Y., Shi, F.L., Wang, D.J., Hao, H.D., Chen, L. (2009). Effects of different hormone proportions on callus induction and differentiation of Melilotoides ruthenica (L.) Sojak cv. Zhilixing. Journal of Inner Mongolia University. 40(3): 297-302.
Campbell, T.A., Bao, G., Xia, Z.L. (1999). Completion of the agronomic evaluations of Medicago ruthenica [(L.) Ledebour] germplasm collected in Inner Mongolia. Genetic Resources and Crop Evolution. 46: 477-484.

Guan, B., Zhou, D., Zhang, H., Tian, Y., Japhet, W., Wang, P. (2009). Germination responses of Medicago ruthenica seeds to salinity, alkalinity and temperature. Journal of Arid Environments. 73(1): 135-138.

Jin, H., Li, G.,Wu, Y.F. (1997). Studies on the histology of organogenesis in isolated culture of mature embryo of Melilotoides ruthenicus (L.) Sojak cv.'Zhili'. Acta Agrestia Sinica. 4: 275-280.

Liu, B.L., Zhang, Y., Zhang, K., Fang, H.Z., Zhang, X.M., Fu, R., Qu, X.H. Xu, R. (2016). The efficient tissue culture system of Orostachys fimbriata. Agricultural Sciences. 7: 175180.

Liu, C. (2020). Preliminary study on identification of downstream genes regulated by Medicago ruthenica MrDREB1 transcription factor and its mechanism. Master Thesis, Hohhot, Inner Mongolia, China.

Liu, S.J., Wang, K.P., Yan, R.Q. (1990). Tissue culture of Medicago ruthenica. Journal of Industrial Technological Economics. 2: 28-29.

Mahmood, I. and Razzaq, A. (2017). Responses of explant type of wheat (Triticum aestivum L.) genotypes to different tissue culture media. J. Natn Sci Foundation Sri Lanka. 45(3): 265-271.

Mehmet, Ö., Sandeep, K.V., Günce, Ş., Nusret, Z., Ekrem, G. (2021). In vitro tissue culture protocol of ancient einkorn (Triticum monococcum ssp. monococum) wheat via indirect shoot regeneration. In-vitro Cellular and Developmental Biology. 57(1): 143-151.

Mehtab, M.A., Joseph, K.K., Zhang, Q., Lin, H.F., Xia, T.Y., Kashif, A., Liu, J.P., Miao, R., Xu, F.Y., Xu, W.F. (2020). In vitro regeneration potential of white lupin (Lupinus albus) from cotyledonary nodes. Plants. 9(3): 318-318.

Miroshnichenko, D., Chaban, I., Chernobrovkina, M., Dolgov, S. (2017). Protocol for efficient regulation of in vitro morphogenesis in einkorn (Triticum monococcum L.), a recalcitrant diploid wheat species. Plos One. 12(3): e0173533.

Ruduś, I., Kępczyński, J., Kępczyńska, Ewa. (2001). The influence of the jasmonates and abscisic acid on callus growth and somatic embryogenesis in Medicago sativa L. tissue culture. Acta Physiologiae Plantarum. 23(1): 103-107.

Sarker, R.H. and Biswas, A. (2002). In vitro plantlet regeneration and agrobacterium mediated genetic transformation of wheat (Triticum aestivum L.). Plant Tissue Culture and Biotechnology. 12(2): 155-165.

Shu, Y.J., Li, Wei, Zhao, J.Y., Liu, Y., Guo, C.H. (2018). Transcriptome sequencing and expression profiling of genes involved in the response to abiotic stress in Medicago ruthenica. Genetics and Molecular Biology. 41(3): 638-648.

Takatsuka, H. and Umeda, M. (2014). Hormonal control of cell division and elongation along differentiation trajectories in roots. Journal of Experimental Botany. 65: 2633-2643.

Tao, R., Li, Y.Z., Wang, J., An, H.H., Guo, J., Shi, S.L. (2011). Protoplasts isolation conditions of Melilotoides ruthenica callus. Acta Agrestia Sinica. 19(2): 288-293. 
Verma, S.K., Das, A.K., Cingöz, S.G., Uslu, E., Gurel, E. (2016). Influence of nutrient media on callus induction, somatic embryogenesis and plant regeneration in selected Turkish crocus species. Biotechnology Reports. 10: 66-74.

Wang, Y.F., Zhang, Y.M., Liu, D.M., Shen, Y.F., Wang, H.Q. (2020). Development and verification of EST-SSR markers in Medicago archiducis-nicolai by transcriptome sequencing. Pratacultural Science. 37(4): 718-727.

Wu, R.N., Shi, F.L., Xu, B., Zhang, Y.T. (2020). Research progress and potential applications for the abiotic stress-resistant forage plant Medicago ruthenica. Pratacultural Science. 37(9): 1845-1854.

Xu, B., Wu, R.N., Tang, F., Gao, C.P., Gao, X., Shi, F.L. (2021). Haploid culture and double haploid induction in Medicago sativa L. cv. XinJiangDaYe. Legume Research. 44(3): 275-280.
Yang, J.Y., Zheng, W., Tian, Y., Wu, Y., Zhou, D.W. (2011). Effects of various mixed salt-alkaline stresses on growth, photosynthesis and photosynthetic pigment concentrations of Medicago ruthenica seedlings. Photosynthetica. 49: 275-284.

Yin, M., Zhang, S.Z., Du, X., Mateo, R.G., Guo, W., Li, A., Wang, Z.Y., Wu, S., Chen, J.Y., Liu, J.Q., Ren, G.P. (2021). Genomic analysis of Medicago ruthenica provides insights into its tolerance to abiotic stress and demographic history. Molecular Ecology Resources. 21(5): 1641-1657.

Zhang, Y.Y., Wang Z.L., Liu G.D., Hu H.F., Du J.C., Zhao, L.L. (2009). Study on the conditions for callus induction and callus differentiation of Melilotoides ruthenica. Chinese Journal of Grassland. 31(4): 74-79. 